\title{
Partycypacja mediów cyfrowych w szkole w opinii młodych dorosłych z pokolenia sieci - perspektywa konfliktu czy rozwoju?
}

\begin{abstract}
Streszczenie
Tekst jest komunikatem z badań przeprowadzonych wśród studentów pierwszego roku pedagogiki - absolwentów kształcenia średniego, należących do pokolenia sieci i aktywnie zanurzonych w mobilnej kulturze cyfrowej. Celem artykułu jest analiza procesu partycypacji technologii cyfrowych w procesie kształcenia. Autor stawia tezę, że technologie cyfrowe można traktować jako zasoby kulturowe, zatem kształtowanie umiejętności ich twórczego wykorzystania jest podstawą nowoczesnej edukacji. Opinie badanych studentów służą odpowiedzi na pytanie zawarte w temacie tekstu, czy i w jakim stopniu kultura szkoły towarzyszy i wzmacnia kulturę mobilną, przygotowując do świadomego i odpowiedzialnego funkcjonowania uczniów w świecie cyfrowym. Badania prowadzą do wniosku, iż młodzi dorośli jako użytkownicy mobilnych mediów w zdecydowanej większości wyrażają swoje rozczarowanie jakością edukacji medialnej w placówkach, których są absolwentami.
\end{abstract}

\section{Słowa kluczowe:}

pokolenie mobilne, kultura szkoły, technologie cyfrowe, proces kształcenia

1 Katarzyna Borawska-Kalbarczyk, Wydział Pedagogiki i Psychologii, Uniwersytet w Białymstoku, Polska, e-mail: borawska@uwb.edu.pl, ORCID ID: https://orcid.org/0000-00034315-2226. 


\begin{abstract}
The article is the research report of study conducted among first-year students of pedagogy - graduates of secondary education, belonging to the network generation and actively immersed in the digital mobile culture. The aim of the article is to analyze the process of participation of digital technologies in the education process. The author formulates the thesis that digital technologies can be treated as cultural resources, therefore shaping the skills of their creative use is the basis of modern education. Opinions of the surveyed students serve to answer the question contained in the topic of the text, whether and to what extent the school culture accompanies and strengthens the mobile culture, preparing for conscious and responsible functioning of students in the digital world. Research leads to the conclusion that young adults as the users of mobile media express their disappointment in the quality of media education in the institutions they are graduates in the vast majority.
\end{abstract}

\title{
Keywords:
}

mobile generation, school culture, digital technologies, teaching process

\section{WPROWADZENIE}

Dokonując rozważań na temat tytułowej partycypacji mediów cyfrowych w procesie kształcenia należy zwrócić na wstępie uwagę na zjawisko postępującej w dynamicznym tempie digitalizacji wielu sfer życia współczesnego człowieka. Zjawisko cyfryzacji to nie chwilowy trend, zarezerwowany dla wybranych grup społecznych czy instytucji, to nasza codzienna rzeczywistość. Wszyscy żyjemy w zdigitalizowanym świecie, którego immanentną częścią są nieustannie przeistaczające się urządzenia medialne. Procesy przenikania, wypierania czy modernizacji tak mediów cyfrowych, jak i zróżnicowanych aplikacji medialnych leżą u podłoża zjawiska konwergencji mediów, którą Henry Jenkins uznał za symbol przejścia od starej do nowej kultury (Jenkins, 2007). Zmiany te generują nowe jakościowo zjawiska modyfikujące dotychczas znane wzorce funkcjonowania jednostek w wielu płaszczyznach życia. Jak zauważa Maciej Tanaś „media cyfrowe stały się nie tylko czynnikiem przeobrażeń społecznych, cywilizacyjnych i kulturowych, ale też zmieniają pośrednio bądź bezpośrednio los każdego niemal człowieka, (...) sposób życia, typy aktywności poznawczej, twórczej, a nawet ludycznej” (Tanaś, 2015, s. 29). Digitalizacja społeczeństwa przyczyniła się do wykreowania specyficznego świata, który - z jednej strony otwiera nieograniczone możliwości kreatywnego wykorzystania cyfrowych narzędzi, zaś z drugiej - generuje równie 
potężne emocje, lęki i obawy, zwykle towarzyszące nowym formom środków masowych. Dychotomia znaczenia nowych technologii we współczesnym świecie jest w równym stopniu odczuwana tak przez jednostki, jak i grupy społeczne oraz instytucje. Jedną z nich jest szkoła - realizująca misję edukowania młodego pokolenia - która wydaje się być nadal w niedostatecznym stopniu podatna na rekonstruowanie swojej kultury pedagogicznej w nurcie procesów digitalizacji rzeczywistości.

Celem artykułu jest analiza procesu partycypacji technologii cyfrowych i aplikacji nowomedialnych w procesie realizacji treści kształcenia. W pierwszej części tekstu dokonam charakterystyki współczesnego pokolenia uczniów jako aktywnych użytkowników kultury medialnej, jak również zwrócę uwagę na jakość procesów edukacyjnych w kontekście przemian współczesności. W drugiej przedstawię wyniki badań sondażowych wskazujących na zakres i poziom wykorzystania technologii cyfrowych w szkole. U podstaw rozważań stawiam tezę, że technologie cyfrowe można traktować jako zasoby kulturowe, zatem kształtowanie umiejętności ich twórczego wykorzystania jest podstawą nowoczesnej edukacji. Opinie młodych użytkowników technologii mobilnych służą odpowiedzi na pytanie, czy i w jakim stopniu kultura szkoły towarzyszy i wzmacnia kulturę mobilną, przygotowując uczniów do świadomej i odpowiedzialnej partycypacji w świecie cyfrowym.

\section{POKOLENIE MOBILNE - SZKIC OBRAZU}

Wraz z analizami ogniskującymi się wokół przemian związanych z rozwojem technologii cyfrowych toczy się równoległy dyskurs dotyczący charakterystyki ich najbardziej aktywnych użytkowników. Grupą społeczną szczególnie podatną na oddziaływanie świata cyfrowych mediów są dzieci i młodzież, określani powszechnie w dyskursie naukowych pojęciem „cyfrowi tubylcy” (por. Prensky, 2001), co wskazuje na ich silne zakotwiczenie w wirtualnej przestrzeni nowych mediów. Proces wychowania i socjalizacji dzieci intensywnie korzystających z nowych mediów realizowany jest w dobie powszechnej kultury cyfrowej, która obecnie wkroczyła dynamicznie w fazę mobilności. Ich cyfrowe uczestnictwo najsilniej związane jest z internetem, a ukształtowane pod przemożnym wpływem technologii i urządzeń mobilnych. Najbardziej oczywistym urządzeniem związanym z codziennym funkcjonowaniem tego pokolenia jest smartfon, umożliwiający natychmiastową łączność z grupami znajomych i światem zewnętrznym. Ważną funkcją mobilnego urządzenia jest stała aktywność w sieciach społecznościowych, 
stąd też w dyskursie społecznym dotyczącym opisu pokolenia cyfrowych tubylców pojawia się określenie „generacja Z” (zob. McCrindle, Wolfinger, 2011), oznaczające grupę młodych ludzi ukształtowanych przez media społecznościowe. Jak zauważa Piotr Sztompka:

każde pokolenie jest nosicielem takiej kultury, która została mu wpojona w dzieciństwie i młodości w procesach socjalizacji czy edukacji. Wiele kierunków psychologii, z psychoanalizą na czele, zauważa, że wczesne doświadczenia życiowe są najsilniejsze i najtrwalsze. Raz zinternalizowanych treści kulturowych trudno się oduczyć, cechują się one znacznym stopniem inercji. W społeczeństwie dzisiejszym, w którym zmiany warunków życia społecznego dokonują się w rytmie ogromnie przyśpieszonym, pokolenie dzieci rodzi się już w kręgu zupełnie innej kultury niż ta, którą nosi jeszcze w sobie pokolenie rodziców (Sztompka, 2012, s. 295).

Należy tu zauważyć, że zmiany technologiczne postępują tak szybko, że coraz częściej używa się określenia „pokolenie Alpha” w odniesieniu do osób urodzonych po 2010 roku (McCrindle, Wolfinger, 2011). Są one potomkami wczesnej generacji Y oraz późnego pokolenia X. Badacze w stosunku do tej - obecnie stosunkowo nielicznej grupy dzieci - prognozują, że będą one najbardziej wykształconym i technologicznie zaawansowanym pokoleniem osób (Gruchoła 2016). Dominujące cechy pokolenia współczesnej młodzieży podsumowuje Thomas Leoncini w rozmowie z Zygmuntem Baumanem: „(...) ciągle przesiadują w sieci, bez przerwy zerkają na telefon komórkowy, zawsze noszą ze sobą najnowocześniejsze i najpłynniejsze nie-miejsce na świecie (internet) i żyją w wiecznym kieszonkowym limbo, które nie istnieje, tworzy relacje tyleż trwałe, co nierzeczywiste” (Bauman, Leoncini, 2018).

Współcześni młodzi ludzie są nieustannie podłączeni do globalnej sieci. Wszystko w ich życiu, zaczynając od komunikacji z rówieśnikami i członkami rodziny, a kończąc na pasjach i rozrywce, jest realizowane z wykorzystaniem urządzeń mobilnych. Pokolenie sieci tworzy nowe enklawy prywatności - właśnie w internecie - gdzie młodzi ludzie zbierają się masowo, nawiązują kontakty z rówieśnikami i tworzą swoje miejsca, do których zapraszają innych. W miarę kurczenia się przyjaznych miejsc w świecie realnym przestrzeń wirtualna zyskuje na atrakcyjności (Tapscott 2010). Sieci społecznościowe dają fenomenalne możliwości rozpowszechniania informacji, komunikacja jest tu natychmiastowa i odbywa się automatycznie, stąd też kontakty za pośrednictwem sieci społecznościowych odgrywają w ich życiu większą rolę niż komunikacja rzeczywista czy 
telefoniczna. Zdaniem Magdaleny Szpunar media społecznościowe „doskonale wpisują się w tendencję aktywizacji użytkowników internetu, umożliwienia im nie tylko biernego odbierania, ale także aktywnego kształtowania sieci i tego, co się w niej dzieje” (Szpunar, 2010, s. 502). Uważa się, że współczesna młodzież jest odpowiedzialna za sukces serwisów społecznościowych, m.in. YouTube czy Facebook. Będąc w permanentnym kontakcie z innymi członkami swojej społeczności, dzięki urządzeniom mobilnym młodzież staje się pokoleniem „wireless” (Hejwosz-Gromkowska, 2015), zanurzonym w świecie wirtualnym, kreując tym samym nowy typ społeczeństwa mobilnego.

Mobilność jako pojęcie, proces i praktyka społeczna zyskuje coraz większe znaczenie we współczesnym świecie, zwiększając zakres rozumienia mobilności w ogóle. Monika Büscher, John Urry i Katian Witchger (2011) wskazują pięć jej typów: podróże cielesne (odnoszące się do ludzi), ruch fizyczny (związany z przedmiotami), podróże wyobrażeniowe (odbywane na podstawie rozmów czy obrazów), podróże wirtualne (wykorzystujące zapośredniczenie technologiczne) oraz podróże komunikatywne (związane z wymianą informacji pomiędzy ludźmi, np. za pośrednictwem listów albo SMS-ów) (Büscher i inni 2011, s. 5). W ujęciu Łukasza Rogowskiego nowe formy mobilności i technologii mobilnych zmieniają sposoby rozumienia przestrzeni, czasu (można użyć tu określenia „miękki czas”) oraz funkcjonowania tożsamości i podmiotowości (Rogowski, 2018). Za pomocą pojęcia mobilność, opisującego metaforę ruchu, dokonywane są analizy ciągłych procesów, którym podlega świat w skali globalnej - odnoszących się do ruchu osób, towarów, idei, usług, informacji. Jak obserwuje J. Urry - współczesna generacja młodzieży Zachodu, w związku z rozwojem technologicznym i konsekwencjami permanentnego multiekranowego informacyjnego przepływu, potrafi realizować wielozmysłowe aktywności - obserwować przekaz z wielu źródeł, śledzić pararelne wątki multimedialne, tworzyć własne gry i inne treści. Zdaniem autora „rozwój takich popiśmiennych multimedialnych umiejętności będzie miał w przyszłości absolutnie centralne znaczenie. Ludzie mogą rozwinąć całe grupy zdolności angażujących wiele zmysłów i związanych z rodzącymi się, nowymi wirtualnymi przedmiotami” (Urry, 2009, s. 107).

Zasygnalizowane wyżej oddziaływanie zjawiska mobilności wzmacniają analizy Manuela Castellsa, który posługując się określeniem „rewolucja mobilna” uznaje ją za część składową społeczeństwa informacyjnego (Castells, 2010). Rozpowszechnianie się komunikacji mobilnej wyraźnie oddziałuje na proces tworzenia się nowej kultury młodzieżowej, transformacje języka, którym się posługujemy, przemiany kulturowe w dziedzinie organizacji czasu i przestrzeni, dotyczące tak jednostki, jak i zespołów ludzkich. 


\section{EDUKACJA SZKOLNA W NURCIE PRZEMIAN TECHNOLOGII CYFROWYCH}

Cechy przekazu urządzeń mobilnych wywołują także istotne zmiany w sposobie posługiwania się tekstem i obrazem, a w konsekwencji modyfikują styl uczenia się współczesnych uczniów. Atrakcyjność aktywności w przestrzeni mobilnej ma swoje przełożenie w oczekiwaniach kierowanych pod adresem szkoły. Młodzi ludzie, funkcjonujący w wielu wymiarach cyfrowego świata, „chcą, aby nauczanie przystawało do rzeczywistego świata (...), chcą, żeby nauka była ciekawa, była dobrą zabawą” (Tapscott, s. 225), a w rzeczywistości można wskazać dowody na istnienie rozziewu między potrzebami uczniów a działaniami dydaktycznymi nauczycieli w sferze realizacji zadań z zakresu edukacji medialnej (por. M. Wrońska, 2015). Przychylam się do opnii Dona Tapscotta (2010), że pokolenie współczesnej młodzieży nie zadowoli się biernym uczestnictwem i wysłuchiwaniem wykładów wygłaszanych przez nauczycieli. Przepaść między tym, jak uczniowie (z pokolenia sieci) myślą, a jaką ofertę kształcenia realizują nauczyciele - bywa źródłem edukacyjnego zniechęcenia, rozczarowania i buntu młodzieży. W przypadku oddziaływania technologii ICT ulega zmianom cała kultura uczenia się, co prowadzi do transformacji tradycyjnie rozumianego modelu edukacji, opartego na relacjach patrialchalnych. Jak wskazuje Manuel Castells (2004), chociaż proces edukacji nadal ma charakter wertyklany, to role zostają odwrócone, a przepływ informacji zmienia kierunek, aby wznosić się od pokolenia młodszego do starszych.

Relacje między kulturą szkoły a kulturą masową (cyfrową, mobilną) upowszechnianą przez nowe media przedstawiane są w opozycyjnym zestawieniu. Maria Czerepaniak-Walczak (2015) wskazuje, że „kultura szkoły” stanowi złożony zestaw formalnych i nieformalnych zasad, poglądów, postaw oddziałujących na całokształt procesu funkcjonowania szkoły. „Tworzą one podstawę wartościowania teraźniejszości oraz wizję przyszłości, rozumienie istoty zasad regulujących życie zbiorowe i warunki zmieniania siebie. Umożliwiają krytyczne, racjonalne i odpowiedzialne uczestniczenie w edukacji, ale w sytuacji ich niespójności mogą być źródłem osobistych i zbiorowych dramatów. Dlatego jednym z celów badania kultury jest poznanie jej zintegrowania, spójności, koherencji i komplementarności jej elementów” (Czerepaniak-Walczak, 2015, s. 80).

Kultura szkolna może mieć pozytywny wpływ na proces uczenia się, podobnie jak może poważnie zagrozić realizacji jej edukacyjnej misji. W myśl nowoczesnych trendów edukacyjnych ważnym celem szkoły jest kształcenie niezależności i samodzielności poznawczej uczniów. Jest to możliwe tylko w sytuacji rozwinięcia przez szkołę kultury, która zachęca uczniów do krytycznego rozwiązywania problemów, rozumiejąc znaczenie samodzielnego konstruowania wiedzy i kreowania atmosfery 
do pracy twórczej. „Kultura nadaje nauczycielom znaczenie, jak zachowywać się w całym procesie edukacyjnym, a także uczniom, jak stworzyć pozytywny klimat w klasie, aby mogli w pełni wykorzystać potencjał, który pomaga im szybko i skutecznie uczyć się lekcji i zdobywać niezbędne kompetencje” (Brankovic, Rodić, 2012, s. 46). Jakość kultury szkoły może więc z jednej strony ułatwiać dostosowanie się jej do nieustannie zmieniającej się rzeczywistości, zaś z drugiej strony może ten proces czynić trudniejszym. Kultura szkoły wytwarza więc swoisty kontekst, kształtowany przez zasady, poglądy, przekonania wszystkich podmiotów edukacyjnych składających się na podłoże realizacji procesu kształcenia.

Obserwując współcześnie działalność edukacyjną szkoły, można wyrazić pogląd, że dominujące jest przeświadczenie - charakterystyczne dla wielu kultur - a wyrażane przez osoby kreujące proces kształcenia, iż rzeczywistość składa się ze stałych i niezmiennych struktur. W myśl analiz dokonanych przez Piotra Błajeta (2015) w edukacji konieczne jest, z jednej strony zakorzenienie w tradycji i kulturze, a z drugiej strony nieustanne poszukiwanie i otwarcie na nowe nurty i inne perspektywy. Tymczasem w obliczu dynamicznych zmian wywołanych nieustannym rozwojem technologii cyfrowych dostrzega się jednak trudność zaangażowania szkoły w praktyki nowomedialne postrzegane jako wsparcie tradycyjnego procesu kształcenia. Do nierzadkich należy pozostawanie kultury szkoły w zaburzonej relacji ze zdarzeniami i zjawiskami rzeczywistości, w której szkoła funkcjonuje, analizowanymi zwłaszcza w kontekście rozwoju technologicznego. Wizerunek szkoły, jaki powszechnie utrwalił się nam w pamięci, wywodzący się epoki industrialnej „eksponuje wyrazisty rozkład ról w teatrze życia szkoły, przekonuje o istnieniu wiedzy pewnej, oczekuje koncentracji na przedmiocie, odkłada gratyfikację za podejmowany wysiłek w rytm obietnic o jego potencjalnej przydatności. Ma się za »westalkę kulturowego ognia « z dostępem do jedynie cennego obiegu »kulturowego dymu«” (Kasprzak, Kłakówna, Kołodziej, Regiewicz, Waligóra, 2016, s. 50). Podstawowe bariery zmiany kultury dydaktycznej szkoły tkwią w niej samej. Będąc często „nieświadomą zmian zachodzących w kulturze, a więc niekompetentną w ich odczytywaniu i kreatywnym w nich uczestnictwie” (Klus-Stańska, 2005, s. 30) szkoła zdaje się nie dostrzegać obecności i znaczenia technologii informacyjnych w życiu swoich uczniów, zaniedbując jakże ważny cel kształtowania kompetencji kreatywnego i odpowiedzialnego użytkowania cyberprzestrzeni. 


\section{ZAŁOŻENIA METODOLOGICZNE BADAŃ}

W kontekście niniejszego artykułu obszarem analizy jest potencjał uczenia się kreowany przez współczesny model edukacji, a wynikający z wielorakich form uczestnictwa pokolenia uczniów w kulturze mobilnej. Wielokrotnie nie sposób ulec wrażeniu, że świat digital natives (uczniowie) i edukacyjna przestrzeń kreowana przez digital immigrants (nauczyciele) to dwie odrębne płaszczyzny, określane przez diametralnie odmienne zestawy celów, motywy działania czy środki realizacji. Dostrzegając edukacyjny potencjał technologii cyfrowych stawiam pytania diagnostyczne: Jaki jest poziom partycypacji mediów cyfrowych, w edukacji? Jakie są oczekiwania, jak i rozczarowania młodych dorosłych w odniesieniu do partycypacji urządzeń i aplikacji cyfrowych w procesie kształcenia? Analiza wyników badań związanych w wymienionymi problemami posłuży próbie odpowiedzi na pytanie, czy i w jakim stopniu kultura szkoły towarzyszy i wzmacnia kulturę mobilną, przygotowując do świadomego i odpowiedzialnego funkcjonowania uczniów w świecie cyfrowym?

Pytania te stały się inspiracją do przeprowadzenia badań wśród studentów kończących pierwszy rok studiów licencjackich na kierunku pedagogika. Do wyboru tej grupy skłoniło mnie kilka determinantów - pierwszym z nich była bezdyskusyjna przynależność do pokolenia mobilnych użytkowników mediów. Po drugie kierowałam się założeniem, że studenci dzieląc się swoimi doświadczeniami związanymi z wykorzystaniem technologii cyfrowej w swojej przeszłości edukacyjnej (etap szkoły średniej) potrafią dokonać tej analizy przez pryzmat wiedzy zdobytej w toku kształcenia akademickiego na temat istoty i uwarunkowań współczesnego modelu procesu kształcenia (zajęcia z dydaktyki ogólnej, pedeutologii czy technologii informacyjnej).

W badaniu uczestniczyło 208 studentów. Metodą badawczą był sondaż diagnostyczny z wykorzystaniem techniki ankiety. Do analizy końcowej wykorzystano 186 kwestionariuszy ankiet. Badania przeprowadzono w maju 2018 roku Zdecydowaną większość badanych stanowiły studentki (94,1\%), przy udziale 5,9\% mężczyzn. Absolwenci liceów ogólnokształcących stanowili 80\% ogółu badanych, zaś studentów, którzy ukończyli technika, było 20,4\%. Szkoła średnia, do której uczęszczali, zlokalizowana była w czterech odmiennych administracyjnie środowiskach: duże miasto (wojewódzkie): 45,2\%, miasto powiatowe: 40,0\%, małe miasto (gmina): $12,9 \%$ oraz szkoła na wsi: $2,2 \%$. Środowiskiem życia największego odsetka studentów było małe miasto (43,6\%), następnie duże miasto (33,3\%) i wieś $(23,1 \%)$. 


\section{WYNIKI BADAŃ}

Niezaprzeczalnym faktem jest, że współczesne pokolenie jest „stale podłączone”, żyjąc w schemacie 24/7/52/356, za pośrednictwem mobilnych urządzeń, które mają ze sobą wszędzie. Maciej M. Sysło (b.d.) słusznie zauważa, że „uczniów nie można odłączyć, bo połączenie jest nie tylko medium, a stanem świadomości”. Oczywiste jest, że narzędzia te powinny znaleźć twórcze zastosowanie także w edukacji, która nie może walczyć z digitalizacją młodzieży. Jest to proces nieuchronny, postępujący, rozwijający się w nieznanym kierunku, który nauczyciele powinni dostrzec i zaakceptować, a następnie włączyć w nurt własnych dydaktycznych oddziaływań, aby wzmocnić edukacyjną atrakcyjność procesu kształcenia, a przede wszystkim wychowywać uczniów do mądrego i rozsądnego korzystania z mediów.

W świetle uzyskanych wyników badań o częstotliwość użycia urządzeń cyfrowej technologii okazuje się, że urządzenia mobilne w zasadzie nie są obecne w procesie kształcenia (tabela 1). Prawie wszyscy studenci (91,9\%) wskazali, że tablet był wykorzystywany sporadycznie lub nigdy, co w połączeniu z 6,5\% odsetkiem badanych deklarujących rzadkie użycie świadczy o jego całkowitym pominięciu w pracy dydaktycznej.

Tabela 1. Częstotliwość użycia urządzeń technologii cyfrowej w szkole średniej w opinii uczniów

\begin{tabular}{|c|c|c|c|c|c|c|c|c|c|c|c|c|}
\hline \multirow{3}{*}{$\begin{array}{l}\text { Urządzenie techno- } \\
\text { logii cyfrowej }\end{array}$} & \multicolumn{10}{|c|}{ Częstotliwość użycia } & \multirow{2}{*}{\multicolumn{2}{|c|}{ Razem }} \\
\hline & \multicolumn{2}{|c|}{$\begin{array}{l}\text { nigdy / } \\
\text { bardzo } \\
\text { rzadko }\end{array}$} & \multicolumn{2}{|c|}{ rzadko } & \multicolumn{2}{|c|}{ czasami } & \multicolumn{2}{|c|}{ często } & \multicolumn{2}{|c|}{$\begin{array}{l}\text { bardzo } \\
\text { często / } \\
\text { zawsze }\end{array}$} & & \\
\hline & $\mathbf{L}$ & $\%$ & $\mathbf{L}$ & $\%$ & $\mathbf{L}$ & $\%$ & $\mathbf{L}$ & $\%$ & $\mathbf{L}$ & $\%$ & $\mathbf{L}$ & $\%$ \\
\hline $\begin{array}{l}\text { komputer stacjo- } \\
\text { narny }\end{array}$ & 30 & 16,1 & 35 & 18,8 & 42 & 22,6 & 26 & 14,1 & 53 & 28,5 & 186 & 100,0 \\
\hline laptop & 54 & 29,0 & 20 & 10,8 & 30 & 16,1 & 43 & 23,1 & 39 & 21,0 & 186 & 100,0 \\
\hline tablet & 171 & 91,9 & 12 & 6,5 & 3 & 1,6 & 0 & 0,0 & 0 & 0,0 & 186 & 100,0 \\
\hline tablica interaktywna & 55 & 29,6 & 21 & 11,3 & 37 & 20,0 & 37 & 20,0 & 36 & 19,4 & 186 & 100,0 \\
\hline $\begin{array}{l}\text { urządzenie mobilne } \\
\text { ucznia }\end{array}$ & 105 & 56,5 & 26 & 14,0 & 24 & 12,9 & 17 & 9,1 & 14 & 7,5 & 186 & 100,0 \\
\hline $\begin{array}{l}\text { rzutnik } \\
\text { multimedialny }\end{array}$ & 16 & 8,6 & 15 & 8,1 & 21 & 11,3 & 49 & 29,3 & 85 & 45,7 & 186 & 100,0 \\
\hline odtwarzacz DVD & 55 & 29,6 & 38 & 20,4 & 39 & 21,0 & 32 & 17,2 & 22 & 11,8 & 186 & 100,0 \\
\hline odtwarzacz CD & 45 & 24,2 & 35 & 18,8 & 26 & 18,8 & 38 & 20,4 & 33 & 17,7 & 186 & 100,0 \\
\hline
\end{tabular}

Źródło: badania własne. 
Przeważająca część ankietowanych zaznaczyła, że nigdy nie lub bardzo rzadko doświadczyła możliwości wykorzystania na lekcji własnego urządzenia mobilnego (56,5\%). Realizacja idei „bring your own device” (BYOD) wystąpiła w kształceniu niewielu ponad 16\% uczniów. Warto tu przytoczyć wypowiedź jednej z badanych: „Szkoła miała tablety zakupione w ramach projektu, ale nie wykorzystywano ich na lekcjach z powodu braku czasu” (K, T, mp, w) ${ }^{2}$.

Częstotliwość pracy ucznia i nauczyciel z komputerem stacjonarnym rozkłada się w miarę równomiernie - 42,6\% badanych wspomina, że używano go w ich szkołach bardzo często i często, zaś rzadkie użycie w toku lekcji przejawia się w deklaracjach 34,9\% studentów. W dostępnej gamie mediów elektronicznych nieco gorzej sytuuje się laptop, którego rzadkie i bardzo rzadkie użycie wskazało 39,8\% badanej grupy, w porównaniu z 44,1\% badanych wskazujących częstsze użytkowanie. Jeden zbadanych wspomina: „była obietnica korzystania na lekcji z laptopa, po czym skończyło się na jednym razie” (K, LO, mp, w).

Dominującym sprzętem stosowanym przez nauczycieli do unowocześnienia zajęć jest rzutnik multimedialny (45,7\% deklaracji stosowania często lub zawsze). Popularność wykorzystania rzutnika w połączeniu z deklarowaną częstością pracy z komputerem stacjonarnym należy ukazać na tle jakości pracy z tymi urządzeniami. Posłużę się tu analizą odpowiedzi na otwarte pytanie skierowane do studentów o negatywne przykłady wykorzystania urządzeń cyfrowych. Wyłania się tu obraz sztampowej lekcji w oparciu o rzekomo aktywizujące metody kształcenia i nowoczesne środki, która ogniskuje się wokół czytania prezentacji w programie Power Point, Wordzie lub w formacie pdf, przygotowanej przez nauczyciela (częściej) lub uczniów (rzadziej):

- Bardzo często były prezentacje nauczycieli w Power Poincie, na których umieszczano ściany tekstu, najczęściej skopiowanego z Wikipedii i czytano go (M, LO, mp, mm);

- Nauczyciel wyświetla prezentację multimedialnq, wybiera ucznia, który zmienia slajdy, a reszta klasy ma czytać w ciszy (K, LO, mp, mm);

- Nauczyciel włączył uczniom gotowq notatkę, którq jedynie przeczytał, nie starał się zobrazować tematu, ograniczył się jedynie do przeczytania (K, LO, mp, mm);

- Prezentacja zalana tekstem, nieczytelna (K, LO, mw, w);

- Wyświetlanie prezentacji w Power Point i odczytywanie przez nauczyciela (K, LO, mg, w);

2 K - kobieta, M - mężczyzna, mw - absolwent szkoły w mieście wojewódzkim, mp - absolwent szkoły w mieście powiatowym, mm - absolwent szkoły w mieście gminnym, w - absolwent szkoły wiejskiej; dm - mieszkaniec dużego miasta, mm - mieszkaniec małego miasta, mw - mieszkaniec wsi. 
- Na lekcji historii pokazywano prezentacje uczniów. Nie były one poprawne merytorycznie, niestarannie wykonane i nieinteresujqce (K, LO, mp, mm);

- Na matematyce nauczycielka wyświetlała ksiq̨żkę na rzutniku, chociaż większość uczniów miała swoje ksiq̨żki (K, LO, mw, dm).

Za symbol nowoczesności w edukacji uchodzą tablice interaktywne, chociaż, jak wskazują wyniki sondażu, nie są same w sobie żadną innowacją, a raczej niestety wzmacniają tradycyjną dydaktykę (wyświetlanie prezentacji, zastępowanie rzutnika). W opinii ponad $40 \%$ badanych mimo posiadania przez szkoły tablic multimedialnych były one wykorzystywane bardzo rzadko lub nigdy (nawet w tak uproszczonej fukcji). Ten niepokojący obraz wzmacniają następujące, najbardziej częste wypowiedzi badanych:

- W mojej szkole były tablice interaktywne, które nigdy nie były użyte (K, LO, mw, dm);

- Zakaz korzystania z tablic interaktywnych, projektorów, zestawów słuchawkowych (K, LO, mw, dm)

- Nie wykorzystywano tablic interaktywnych z powodu tego, że nauczyciel nie umiał ich obsługiwać (K, LO, mp, mm);

- Tekst był wyświetlany na tablicy interaktywnej do przepisania (K, LO, mw, $\mathrm{mm})$;

- Posiadaliśmy tablicę interaktywnq w sali od niemieckiego i nie wykorzystaliśmy jej ani razu przez trzy lata (K, LO, mw, dm);

- W mojej szkole nauczyciele nie umieli obsługiwać tablicy interaktywnej i nie pozwalali dotykać jej uczniom (M, LO, pw, mm).

Z drugiej strony według deklaracji ponad 1/3 respondentów (39,4\%) tablica interaktywna nie służyła jedynie jako ozdoba klasy i pozorowany przejaw nowoczesności szkoły, gdyż była wykorzystywana zgodnie ze swoim przeznaczeniem dość często:

- Były zajęcia z matematyki z tablicq interaktywnq, na której były zadania. Uczeń mógł się wykazać wiedzq i rozwiqzać zadanie, jeżeli było poprawnie wykonane to wyświetlało się kolejne, nowe zadanie (K, LO, mw, mm);

- Na lekcji angielskiego poprzez tablicę interaktywnq można było dopasować słówka do definicji i tworzyć obrazki (K, LO, mp, mm);

- Na lekcji matematyki często była praca z tablicq interaktywnq, co bardziej rozwija wyobraźnię dotyczq̨cq danego tematu (K, LO, mw, dm);

- Na lekcjach chemii używaliśmy tablicy interaktywnej i oglądaliśmy doświadczenia, których nie mogliśmy zrobić w szkole i potem były różne zadania na tablicy (K, LO, mw, dm); 
- Na lekcjach języka angielskiego wykorzystywaliśmy tablicę interaktywnq, na której były wyświetlane gry, miały na celu ciekawy sposób nauki języka - były to memorki, fiszki i gry strategiczne. Na tego typu lekcje chętnie uczniowie przychodzili (K, LO, mp, dm).

Dodatkowo zapytano się o deklarowaną częstość wykorzystania odtwarzaczy DVD i CD. Jak się okazuje, połowa badanych stwierdziła, że sprzęt do odtwarzania filmów był wykorzystywany sporadycznie (nigdy lub bardzo rzadko), zaś w opinii co trzeciego studenta bardzo często i często. Częstotliwość użycia popularnego środka technicznego do odtwarzania dźwięków sytuowała się na podobnym poziomie: 43\% badanych wspominała rzadkie lub bardzo rzadkie użycie, a 38,1\% - częste i bardzo częste.

Interesującym wydało się także sprawdzenie, w jakich miejscach uczniowie mają możliwość pracy z nowoczesnym sprzętem cyfrowym (tabela 2). Z uzyskanych danych wynika, że zdecydowana większość zajęć, na których uczniowie mają kontakt z urządzeniem TIK, to pracownia komputerowa, w której odbywają się lekcje informatyki (59,7\% wskazań kategorii „często” i „bardzo często”). W szkołach blisko połowy uczniów (44,6\%) zajęcia odbywały się równie często w salach przedmiotowych wyposażonych w urządzenia technologii informacyjnej.

Tabela 2. Miejsca wykorzystania urządzeń technologii cyfrowej

\begin{tabular}{|c|c|c|c|c|c|c|c|c|c|c|c|c|}
\hline \multirow{3}{*}{$\begin{array}{l}\text { Miejsce } \\
\text { wykorzystania }\end{array}$} & \multicolumn{10}{|c|}{ Częstotliwość użycia } & \multirow{2}{*}{\multicolumn{2}{|c|}{ Razem }} \\
\hline & \multicolumn{2}{|c|}{$\begin{array}{l}\text { bardzo } \\
\text { rzadko }\end{array}$} & \multicolumn{2}{|c|}{ rzadko } & \multicolumn{2}{|c|}{ czasami } & \multicolumn{2}{|c|}{ często } & \multicolumn{2}{|c|}{$\begin{array}{l}\text { bardzo } \\
\text { często }\end{array}$} & & \\
\hline & $\mathbf{L}$ & $\%$ & $\mathbf{L}$ & $\%$ & $\mathbf{L}$ & $\%$ & $\mathbf{L}$ & $\%$ & $\mathbf{L}$ & $\%$ & $\mathbf{L}$ & $\%$ \\
\hline $\begin{array}{l}\text { pracownia kom- } \\
\text { puterowa }\end{array}$ & 14 & 7,5 & 25 & 13,4 & 36 & 19,4 & 35 & 18,8 & 76 & 40,9 & 186 & 100,0 \\
\hline sala lekcyjna & 24 & 12,9 & 23 & 12,4 & 56 & 30,1 & 55 & 29,6 & 28 & 15,0 & 186 & 100,0 \\
\hline $\begin{array}{l}\text { sala lekcyjna } \\
\text { z WiFi - BYOD }\end{array}$ & 86 & 46,2 & 37 & 20,0 & 20 & 10,75 & 22 & 11,8 & 21 & 11,3 & 186 & 100,0 \\
\hline $\begin{array}{l}\text { czytelnia/ } \\
\text { biblioteka }\end{array}$ & 48 & 25,8 & 39 & 21,0 & 43 & 23,1 & 30 & 16,3 & 26 & 14,0 & 186 & 100,0 \\
\hline
\end{tabular}

Źródło: badania własne.

Do rzadkości należały sytuacje, w których możliwa była praca z własnym urządzeniem mobilnym w klasie z dostępem do szerokopasmowego internetu (66,0\% ankietowanych wskazało, że taka sytuacja miała miejsce bardzo rzadko lub nigdy, zaś jedynie co czwarty - 23,1\% badanych - że często i bardzo często). Biblioteka i czytelnia jest miejscem, w którym także rzadko w opinii studentów była możliwość pracy z technologią informacyjną (46,8\% wskazań „rzadko” i „bardzo rzadko”). 
Współczesny poziom zaawansowania ICT gwarantuje projektom edukacyjnym narzędziowe wsparcie, ale realizacja zadań dydaktycznych zależy wyłącznie od kompetentnego ich wykorzystania i zastosowania.

Analizując wynikające z badań częstotliwości pracy z aplikacjami wzbogacającymi realizację procesu kształcenia (tabela 3), dostrzega się, że cała gama programów rozwijających kreatywność, wyobraźnię, pomysłowość, zdolności poznawcze, umiejętności kategoryzowania, logicznego myślenia jest wykorzystywana w stopniu marginalnym (deklaracje przeważającej liczby respondentów oscylujące wokół 80\% wskazań kategorii „rzadko” lub „bardzo rzadko”). Można przypuszczać, że wsparcie ucznia w aktywnym, poznawczym przetwarzaniu informacji podczas lekcji z wykorzystaniem ICT jest przez nauczycieli bagatelizowane $\mathrm{i}$ ignorowane.

Tabela 3. Częstotliwość aplikacji wykorzystywanych w celach edukacyjnych w opinii uczniów

\begin{tabular}{|c|c|c|c|c|c|c|c|c|c|c|c|c|}
\hline \multirow[t]{3}{*}{ Program / aplika } & \multicolumn{10}{|c|}{ Częstotliwość użycia } & \multirow{2}{*}{\multicolumn{2}{|c|}{ Razem }} \\
\hline & \multicolumn{2}{|c|}{$\begin{array}{l}\text { bardzo } \\
\text { rzadko }\end{array}$} & \multicolumn{2}{|c|}{ rzadko } & \multicolumn{2}{|c|}{ czasami } & \multicolumn{2}{|c|}{ często } & \multicolumn{2}{|c|}{$\begin{array}{l}\text { bardzo } \\
\text { często }\end{array}$} & & \\
\hline & $\mathbf{L}$ & $\%$ & $\mathbf{L}$ & $\%$ & $\mathbf{L}$ & $\%$ & $\mathbf{L}$ & $\%$ & $\mathbf{L}$ & $\%$ & $\mathbf{L}$ & $\%$ \\
\hline $\begin{array}{l}\text { program do prezen- } \\
\text { tacji }\end{array}$ & 15 & 8,1 & 25 & 13,4 & 33 & 17,7 & 29 & 15,6 & 84 & 45,2 & 186 & 100,0 \\
\hline $\begin{array}{l}\text { program do edycji } \\
\text { tekstu }\end{array}$ & 22 & 11,8 & 20 & 10,6 & 35 & 18,8 & 36 & 19,4 & 74 & 39,8 & 186 & 100,0 \\
\hline $\begin{array}{l}\text { progran } \\
\text { cyjny }\end{array}$ & 74 & 39,8 & 39 & 21,0 & 35 & 18,8 & 13 & 7,0 & 25 & 13,4 & 186 & 100,0 \\
\hline program graficzny & 149 & 80,1 & 21 & 11,3 & 7 & 3,8 & 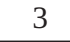 & 1,6 & 6 & 3,2 & 186 & 100,0 \\
\hline program d & 161 & 86,6 & 12 & 6,5 & 7 & 3,8 & 4 & 2,2 & 2 & 1,1 & 186 & 100,0 \\
\hline $\begin{array}{l}\text { program do edycji } \\
\text { filmów }\end{array}$ & 153 & 83,9 & 14 & 7,5 & 10 & 5,4 & 5 & 2,7 & 4 & 2,6 & 186 & 100,0 \\
\hline $\begin{array}{l}\text { aplikacje do progra- } \\
\text { mowania }\end{array}$ & 172 & 92,4 & 6 & 3,2 & 3 & 1,6 & 3 & 1,6 & 2 & 1,1 & 186 & 100,0 \\
\hline $\begin{array}{l}\text { programy do ani- } \\
\text { macji }\end{array}$ & 148 & 80,0 & 19 & 10,2 & 14 & 7,5 & 2 & 1,1 & 3 & 1,6 & 186 & 100,0 \\
\hline $\begin{array}{l}\text { programy do tworze- } \\
\text { nia stron WWW }\end{array}$ & 129 & 69,4 & 36 & 19,3 & 16 & 8,6 & 3 & 1,6 & 2 & 1,1 & 186 & 100,0 \\
\hline $\begin{array}{l}\text { narzędzia do wizu- } \\
\text { alizacji }\end{array}$ & 147 & 79,0 & 24 & 12,9 & 7 & 3,8 & 3 & 1,6 & 5 & 2,7 & 186 & 100,0 \\
\hline $\begin{array}{l}\text { aplikacje do porząd- } \\
\text { kowania wiedzy }\end{array}$ & 136 & 73,1 & 31 & 16,7 & 12 & 6,5 & 7 & 6,8 & 0 & 0,0 & 186 & 100,0 \\
\hline
\end{tabular}

Źródło: badania własne. 
Wśród programów najbardziej popularnych dominuje edytor tekstu (60,8\% wskazań kategorii „bardzo często” i „często”), następnie program prezentacyjny (59,2\%) oraz arkusz kalkulacyjny (20,4\%). Z jakościowej analizy badań wykorzystującej swobodne wypowiedzi studentów wynika, że powyższe trzy programy były wykorzystywane w sposób wysoce odtwórczy, w najbardziej schematyczny i uproszczony sposób, wzmacniając reprodukowanie informacji i bierny odbiór treści edukacyjnych.

Analizowany powyżej proces partycypacji technologii cyfrowych w tok zajęć szkolnych uzupełnia opinia o kształtowaniu przez szkołę kompetencji cyfrowych uczniów (wykres 1). W świetle prezentowanych wyżej wyników badań nie jest zaskakujące, że w przeświadczeniu 81\% studentów szkoła w niskim i przeciętnym stopniu wzmocniła ich umiejętności wykorzystywania narzędzi medialnych. Jedynie $26 \%$ badanych było zdania, że wysoki poziom ich umiejętności pracy z narzędziami ICT jest rezultatem oddziaływania zajęć edukacyjnych.

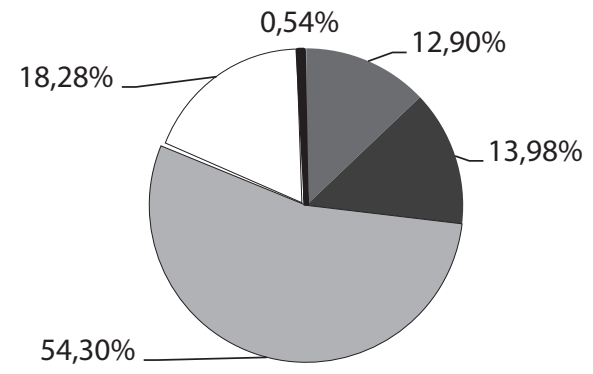

bardzo niski $\square$ niski $\square$ przeciętny $\square$ wysoki $\square$ bardzo wysoki

Wykres 1. Stopień wzmocnienia/rozwoju kompetencji cyfrowych ucznia pod wpływem zajęć szkolnych z wykorzystaniem nowych mediów Źródło: badania własne.

Dopełnieniem obrazu procesu oddziaływania szkoły na kompetencje medialne uczniów jest ocena badanych, kto w największym stopniu przyczynił się do wzmocnienia i rozwijania ich sprawności pracy z technologią cyfrową (wykres 2).

$\mathrm{Z}$ analizy danych wynika, że największą siłę sprawczą w budowaniu własnych kompetencji medialnych badani studenci przypisują sobie - własnej chęci, ciekawości poznawczej, otwartości na nowe narzędzia cyfrowe nieustannie rozwijającego się świata ICT. Jako aktywni użytkownicy mobilnych mediów uczestniczą w procesie permanentnej i otwartej autoedukacji i samorealizacji wynikającej z nieustannych przeobrażeń technologicznych współczesności (deklaracje 60,2\% 
ogółu badanych). Jako tzw. drugie pokolenie cyfrowych tubylców chętnie współpracują z rówieśnikami w procesie poznawania, doświadczania i dzielenia się wiedzą w zakresie nowych możliwości mediów cyfrowych (35,5\% wskazań).

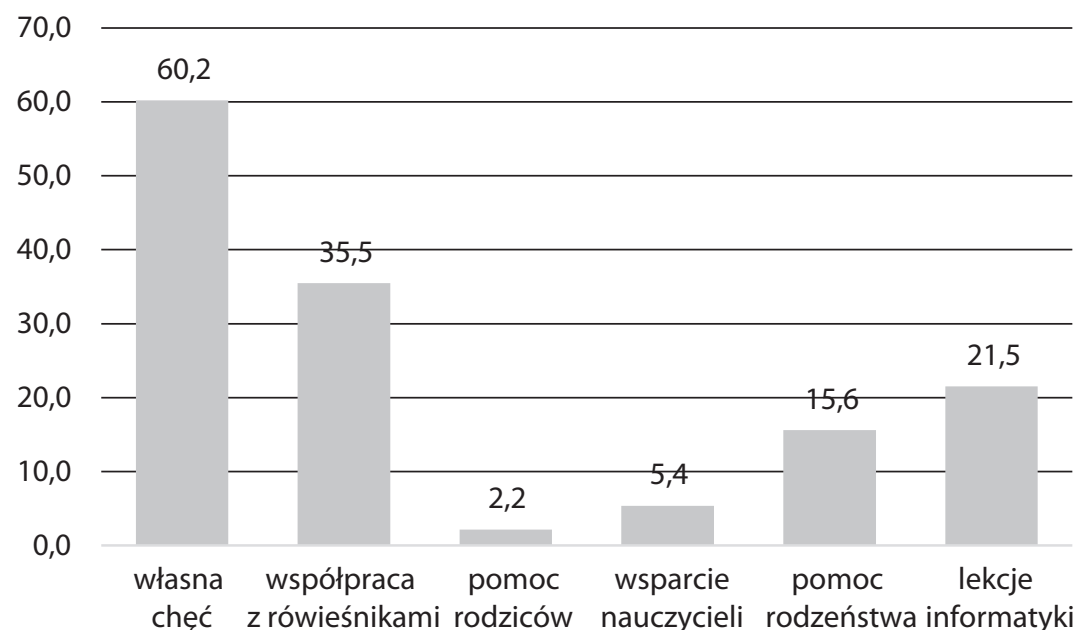

Wykres 2. Źródła wsparcia w rozwoju kompetencji cyfrowych ucznia Źródło: badania własne.

Odsetek studentów wskazujących rodziców i nauczyciel, jako znaczące wsparcie w procesie kształtowania umiejętności medialnych (2,2\% oraz 5,4\%) stanowi jawny dowód, że przynależą oni do grupy cyfrowych imigrantów traktujących nowe media z dystansem, bojaźnią, nieufnością oraz nie legitymują się w ocenie badanych wystarczającymi kwalifikacjami do udzielenia wsparcia swoim podopiecznym. Wyjątkiem są oceny $21 \%$ ankietowanych, wskazujących, że do rozwijania kompetencji cyfrowych przyczyniły się lekcje z informatyki jako przedmiotu kształcenia.

\section{DYSKUSJA WYNIKÓW I WNIOSKI}

W dążeniach do uchwycenia istoty środowiska edukacyjnego w dobie kultury mobilnej - w świecie przesyconym narzędziami ICT, które poprzez swoją multimedialność, hipertekstowość, interaktywność i komunikacyjność pobudzają i motywują do poszukiwań i odkryć - rodzi się wiele wątpliwości i dylematów. Obserwowana ekspansja cyfrowych technologii informacyjno-komunikacyjnych, 
opierająca się na przenośnych urządzeniach cyfrowych i sieciowej łączności ze światem w dowolnym miejscu, kształtuje i modyfikuje wiele warstw życia współczesnego człowieka. Dynamiczny rozwój i upowszechnienie współczesnych technologii stwarza także nową sytuację dla edukacyjnych procesów, analizowaną zarówno w wymiarze jakościowym, jak i ilościowym. Przede wszystkim edukacja nie może pozostać obojętna wobec nowego ucznia, członka cyfrowej generacji mobilnej, ukształtowanego przez technologie. Konieczne staje się wypracowanie specyficznej strategii kształcenia uwzględniającej nawyki mentalne młodego pokolenia, ukształtowanego w „kulturowych warunkach tzw. trzeciej fazy komputeryzacji” (Bougsiaa, Kopciewicz, 2016, s. 143).

W odpowiedzi na postawione pytanie badawcze można wnioskować, iż badana grupa młodych dorosłych, użytkowników mobilnych mediów, w zdecydowanej większości wyraża swoje rozczarowanie jakością edukacji medialnej w placówkach, których są absolwentami. Z drugiej strony jako osoby aktywnie partycypujące w mobilnej kulturze są w stanie generować dojrzałe i refleksyjne oceny związane z wartościami, jakie niesie mądre praktykowanie technologii informacyjnej w edukacji:

- rozwój kreatywności, wyobraźni, innowacyjności, samodzielności, zainteresowań ( $\mathrm{M}, \mathrm{LO}, \mathrm{mp}, \mathrm{mm})$;

- łatwiejsza dostępność i przystępność materiałów, wsparcie nauki, ułatwienie przyswojenia wiedzy (K, LO, mp, mw);

- integracja uczniów, porozumiewanie się z innymi w celu utworzenia np., jakiegoś projektu na portalu społecznościowym (K, LO, mw, dm);

- rozwijajq kreatywność, umiejętność logicznego myślenia, różnicujq̨ zajęcia, sprawiajq, że uczniowie chętniej w nich uczestniczq (K, LO, mw, dm);

- uczeń uczy się wykorzystywać technologię nie tylko do rozrywki i komunikacji ale także do poszerzania swojej wiedzy i zdobywania nowych umiejętności (K, LO, mp, mm);

- bardziej efektywna nauka, bardziej interesujq̨ce, działajq̨e na wyobraźnię zajęcia, co sprawiłoby, że uczniowie chętniej chodziliby do szkoły (K, LO, $\mathrm{mw}, \mathrm{mm})$;

- wszechstronne obycie w świecie wirtualnym (K, T, mp, mw);

- lekcje sq atrakcyjniejsze, młodzi ludzie znajq nowe technologie i ich wykorzystanie na zajęciach jest dla nich „normalne”, nie czujq niechęci (K, LO, mw, mw);

- życie wokół technologii cyfrowych, poruszanie się w ich obrębie doprowadzi do tego, że uczniowie będą ciągle się tym posługiwać, a jest to potrzebne w obecnych czasach. Dzięki nowym technologiom uczeń ma 
szersze możliwości do nauki, nauka jest ciekawsza, gdyż jest to coś innego, wciqgajq̨cego (K, LO, mp, mm);

- nauka staje się przyjemna, uczniowie sq mobilni i szkoła powinna dostosować się do standardów współczesności (K, LO, mw, mw).

Ostatnia z prezentowanych ocen jest swoistym manifestem przynależności młodych do pokolenia mobilnych użytkowników mediów cyfrowych i dowodem dojrzałości poznawczej w procesie krytycznego osądu polskiej rzeczywistości edukacyjnej.

Przeprowadzona analiza wyników badań wskazuje, że edukację definiowaną jako proces ciągły i całożyciowy trzeba w wyważony sposób usytuować w złożonej i przez to niełatwej współczesności. Z jednej strony musi ona mądrze nadążać za technologicznym pędem i przemianami społecznymi i gospodarczymi, które niesie, nie mogąc zostać samotną, okopaną twierdzą zbędnej wiedzy, nieprzystającą do współczesności. Z drugiej strony musi być ostoją cywilizacyjną, która wyznacza i pielęgnuje kanon dorobku kulturowego oraz wzorce moralne i etyczne przyszłych pokoleń (Baron-Polańczyk, 2016).

Twierdzę, że szkoła, która utrwaliła się w pamięci studentów, nie stworzyła dla nich na tyle atrakcyjnego środowisko nauki, aby byli zanurzeni w nim tak, jak w świecie modelowanym przez kulturę mobilną. Są powody do przypuszczeń, że w większości nie znaleźli w szkole możliwości rozwijania swoich zainteresowań i pasji w sposób nowoczesny, adekwatny do doświadczanego przez nich mediamorficznego rozwoju.

Wykreowany przez pryzmat opinii studentów obraz obecności nowych technologii w szkole można przeanalizować na przykładzie modelu SAMR Rubena R. Puentedury (2003), definiującego cztery poziomy integracji technologii w procesie edukacji: Substitiution (podstawienie), Augmentation (powiększenie), Modification (modyfikacja), Redefinition (redefinicja). Zarówno ilościowa, jak i jakościowa ocena wykorzystania narzędzi technologii cyfrowych w szkołach daje podstawy do wnioskowania, że zastosowanie ITC w środowisku kształcenia rzadko osiąga poziom drugi (augmentation), koncentrując się na poziomie substitiution (np. pisanie na tablicy interaktywnej, użycie jej wyłącznie w formie wyświetlania prezentacji). Prowadzi to do sytuacji, w której uczniowie praktycznie nie doświadczają żadnego zysku z używania technologii cyfrowej w edukacji, czego skutecznie dowodzą cytowane wcześniej opinie młodych dorosłych, iż szkoła nie potrafi wykorzystać potencjału możliwości, jaki oferują nowoczesne urządzenia będące w jej posiadaniu.

Podsumowując, w odpowiedzi na dylemat zawarty w tytule niniejszego tekstu: czy zderzenie kultury szkoły z kulturą mobilną uczniów generuje płaszczyznę roz- 
woju, czy konfliktu - wyniki analiz skłaniają do refleksji, że szkoła nadal nie jest przygotowana do wyjścia naprzeciw oczekiwaniom i potrzebom swoich uczniów. Unikanie włączenia nowych technologii we wszystkie płaszczyzny procesu kształcenia wzmacnia istniejącą w szkołach kulturę pozoru, dotykającą omawianą tu perspektywę dydaktyki cyfrowej. Trening zakorzeniania uczniów w opornej na przemiany technologiczne szkolnej kulturze uniemożliwia przełamanie dysonansu między wielowymiarowym zaangażowaniem uczniów w nurt oddziaływań medialnych a jednostronnym, tradycyjnym przekazem treści edukacyjnych. Tym samym wzmacnia indolencję szkoły na płaszczyźnie realizacji celów edukacji medialnej. Niedostrzeganie edukacyjnego potencjału nowych mediów, ich niepełne wykorzytanie lub całkowite ignorowanie równoznaczne jest ze sztucznym odcięciem uczniów od ich codzienności, przenikniętej wszechobecnością technologii.

Szkoła otwarta na potrzeby i różnorodne formy aktywności pozaszkolnej ucznia z pokolenia mobilnego, poszerzająca możliwości zdobywania, przetwarzania i kreowania informacji z zastosowaniem nowoczesnych technologii ma szansę kształtować różnorodne aspekty jego samodzielności poznawczej. Można wśród nich wskazać: dostrzeganie problemów, ich formułowanie, stawianie hipotez, odszukiwanie źródeł informacji, prowadzenie symulacji, uczenie się metodą prób i błędów, prezentację własnych dokonań. Ważnym elementem w procesie szkolnego funkcjonowania ucznia jest także budowanie poczucia sprawstwa. W takim modelu działania ucznia i nauczyciela równoważą się - z przesunięciem akcentu na aktywność osoby uczącej się.

Badanie kultury szkoły w kontekście współczesnej kultury mobilnej jest zjawiskiem wymagającym pogłębionych analiz. Artykuł ten jest jedynie krótką refleksją wywiedzioną z własnej obserwacji oraz analizy wyników badań uzyskanych z obserwacji uczniów (absolwentów) - jako krytycznych uczestników procesu kształcenia. Przychylam się do opinii Davida Buckinghama, że „należy unikać mniemania, iż technologia jest skuteczna sama w sobie. Może posiadać wielki potencjał twórczy, edukacyjny i demokratyczny; lecz to, czy potencjał ten zostanie wykorzystany, zależy od sposobów używania technologii oraz od stosunków społecznych konstruowanych wokół niej” (Buckingham, 2008, s. 168). Potrzebne jest twórcze podejście do zmiany myślenia na temat form edukacyjnego praktykowania i nowych form budowania wspólnoty uczących się, uwzględniając wartości tkwiące w kulturze szkoły i nowoczesne akcenty kultury mobilnej. 


\section{Bibliografia}

Baron-Polańczyk, E. (2016). Model kontinuum środowiska edukacyjnego nauczycieli (chmura - silos). Człowiek - Teraźniejszość - Edukacja, 19 (2 [74]), s. 125-138.

Bauman, Z., Leoncini M. (2018). Płynne pokolenie. Tłum. Sz. Żuchowski. Warszawa: Wydawnictwo Czarna Owca.

Błajet, P. (2015). (Nie)przypadkowa edukacja. Toruń: Wydawnictwo Naukowe Uniwersytetu Mikołaja Kopernika w Toruniu.

Bougsiaa, H., Kopciewicz, L. (2016). Mobilne nastolatki. W: H. Bougsiaa, M. Cackowska, L. Kopciewicz, T. Nowicki (red.), Smartfon i tablet w dziecięcych rękach (s. 142-163). Gdańsk: Wydawnictwo: Katedra.

Brankovic, N., Rodić, V., (2012). Determination of Indicators of School Culture in Primary Schools. The New Educational Review, 3, s. 45-53.

Buckingham, D. (2008). Nowe media, nowe postaci dzieciństwa? W: M.J. Kehily (red.), Wprowadzenie do badań nad dzieciństwem (s. 151-169). Tłum. M. Kościelniak Kraków: Wydawnictwo WAM.

Büscher, M., Urry, J., Witchger, K. (2011). Introduction. Mobile methods. W: M. Büscher, J. Urry, K. Witchger (eds.), Mobile Methods, New York: Routledge.

Castells, M. (2010). Społeczeństwo sieci. Tłum. M. Marody. Warszawa: PWN.

Castells, M., Fernandez-Ardevol, M., Linchuan Qiu J., Sey, A. (2004). The Mobile Communication Society: A cross-cultural analysis of available evidence on the social uses of wireless communication technology. Pobrano z: http://citeseerx.ist.psu.edu/viewdoc/ download?doi=10.1.1.109.3872\&rep=rep1\&type=pdf.

Czerepaniak-Walczak, M. (2015). Kultura szkoły - o jej złożoności i wielowymiarowości. Pedagogika społeczna, 3, s. 77-87.

Gruchoła, M. (2016). Pokolenie Alpha - nowy wymiar tożsamości? Rozprawy Społeczne, 10 (3), s. 5-13.

Hejwosz-Gromkowska, D. (2015). Młodzież, Facebook a problem partycypacji społecznej. Studia Edukacyjne, 35, s. 179-193.

Jenkins, H. (2007). Kultura konwergencji. Zderzenie starych i nowych mediów. Tłum. M. Bernatowicz, M. Filiciak. Warszawa: Wydawnictwo Akademickie i Profesjonalne. Kasprzak, P., Kłakówna, Z.A., Kołodziej, P., Regiewicz, A., Waligóra, A. (2016). Edukacja w czasach cyfrowej zarazy. Toruń: Wydawnictwo Adam Marszałek.

Klus-Stańska, D. (2005). Rzecz o ryzyku kulturowej nieadekwatności edukacji szkolnej. Forum Oświatowe, 17 (1 [32]), s. 23-46.

McCrindle, M., Wolfinger, E. (2011). The ABC of XYZ. Understanding the Global Generations. Sydney: University of New South Wales Press Ltd.

Prensky, M. (2001). Digital Natives, Digital Immigrants. From On the Horizon, 9, 5.

Puentedura, R.R. (2003). A Matrix Model for Designing and Assessing Network-Enhanced Courses. Pobrano z: http://www.hippasus.com/resources/matrixmodel/.

Rogowski, Ł. (2018). Mobilność jako potencjalność: Sposoby rozumienia mobilności. Z perspektywy nowych technologii i paradygmatu mobilności. Ruch Prawniczy, Ekonomiczny i Socjologiczny, LXXX (2), s. 275-276.

Sysło, M.M. (b.d.). Wykorzystanie nowoczesnych technologii w edukacji uczniów zdolnych, ze szczególnym zwróceniem uwagi na potrzeby uczniów o specjalnych potrzebach 
edukacyjnych. Pobrano z: https://www.ore.edu.pl/materiay-do-pobrania-42584/ category/86-materiay-z-konferencji?download=2438: wykorzystanie-owoczesnychtechnologii-w-edukacji-ze-szczeglnym-zwrceniem-uwagi-na-potrzeby-uczniow-o-specjalnych-potrzebach-edukacyjnych.

Szpunar, M. (2010). Prawdziwych przyjaciół poznaje się w Internecie. Serwisy społecznościowe i ich użytkownicy. W: D. Bis, A. Rynio (red.), Media w wychowaniu chrześcijańskim (s. 501-512). Lublin: KUL.

Sztompka, P. (2012). Socjologia. Analiza społeczna. Kraków: Społeczny Instytut Wydawniczy Znak.

Tanaś, M. (2015). Edukacja@cyberprzestrzeń - pola badań i refleksji pedagogicznej. W: D. Morańska (red.), Edukacja w cyberprzestrzeni. Nowe wyzwania i problemy badawcze (s. 27-41). Dąbrowa Górnicza: Wyższa Szkoła Biznesu w Dąbrowie Górniczej. Tapscott, D. (2010). Cyfrowa dorosłość. Jak pokolenie sieci zmienia nasz świat. Tłum. P. Cypryański. Warszawa: Wydawnictwa Akademickie i Profesjonalne.

Urry, J. (2009). Socjologia mobilności. Tłum. J. Stawiński. Warszawa: PWN.

Wrońska, M. (2015). Edukacja szkolna a kultura medialna adolescentów. W: R. Czerski, R. Wawer (red.), Nowoczesne media w przestrzeniach edukacyjnych (s. 37-46). Lublin: Wydawnictwo UMCS w Lublinie.

Wrońska, M. (2018). W stronę inwersji edukacyjnej - czy adolescent może być „mistrzem” dla swojego nauczyciela w cyberprzestrzeni? W: M. Tanaś, S. Galanciak (red.), Cyberprzestrzeń - człowiek - edukacja. Mistrz i uczeń w cyberprzestrzeni (s. 153-163). Kraków: Oficyna Wydawnicza „Impuls”. 